\title{
WADAH INTERAKSI SOSIAL DAN SARANA KREATIF DI KEMAYORAN, JAKARTA PUSAT
}

\author{
Steffi Gisela ${ }^{1}$, Diah Anggraini ${ }^{2)}$ \\ 1) Program Studi S1 Arsitektur, Fakultas Teknik, Universitas Tarumanagara, steffigiselahouw@gmail.com \\ 2) Program Studi S1 Arsitektur, Fakultas Teknik, Universitas Tarumanagara, diaha@ft.untar.ac.id
}

\begin{abstract}
Abstrak
Kebutuhan manusia sebagai makhluk sosial adalah saling berinteraksi. Apalagi dengan padatnya aktivitas dan tuntutan pekerjaan yang tinggi khususnya pada daerah Kemayoran. Pada kawasan tersebut sangat dibutuhkan ruang publik sebagai wadah bagi mereka untuk menunjang kebutuhan sosial mereka. Third place sebagai ruang ketiga diperlukan bagi semua orang karena merupakan tempat dimana orang dapat melepaskan kepenatan yang terjadi pada aktivitas keseharian mereka. Kurangnya third place mengakibatkan berbagai masalah misalnya lalu lintas yang terhambat karena anak-anak bermain bola di tengah jalan, banyaknya warga yang bersantai di pinggir jalan utama ataupun di bunderan, sampai timbulnya parkir liar yang mengakibatkan kemacetan. Oleh karena itu, proyek ini bertujuan untuk menyelesaikan masalah sosial di Kemayoran yang sekaligus meningkatkan kualitas warga Kemayoran melalui sarana kreatif. Dalam membangun program dalam bangunan, dipilih menggunakan metode transprogramming yang dilakukan dengan mengkombinasikan dua program yang sifat dan konfigurasi spasialnya berbeda tanpa melihat kecocokannya. Misalnya perpustakaan dikombinasikan dengan arena balap. Dengan ini diharapkan warga Kemayoran dapat lebih menjalin keakraban dan membangun keharmonisan serta mengembangkan potensinya sehingga akan menaikkan kualitas sosial mereka.
\end{abstract}

Kata kunci: aktivitas; interaksi; Kemayoran; publik; sarana kreatif; sosial

\begin{abstract}
Human needs as social beings are interacting. Especially with the high activity and high work demands, especially in the Kemayoran area. In this area, public space is needed as a place for them to support their social needs. Third place as the third space is needed for everyone because it is a place where people can release the fatigue that occurs in their daily activities. The lack of a third place causes various problems such as traffic that is hampered by children playing soccer in the middle of the road, many residents who relax on the side of the main road or roundabouts, to the emergence of illegal parking which causes traffic jams. Therefore, this project aims to resolve social problems in Kemayoran which simultaneously improve the quality of Kemayoran residents through creative means. In building programs in buildings, it is chosen to use the transprogramming method which is done by combining two programs whose properties and spatial configurations are different regardless of their suitability. For example the library is combined with a racecourse. With this, it is hoped that Kemayoran residents can further develop intimacy and build harmony and develop their potential so that they will improve their social quality.
\end{abstract}

Keywords: activity; creative hub; interaction; Kemayoran; public; social

\section{PENDAHULUAN \\ LATAR BELAKANG}

Setiap manusia membutuhkan sarana untuk menyegarkan pikirannya dan kembali bekerja dengan baik. Apalagi dengan tuntutan pekerjaan yang semakin tinggi, yang mengakibatkan seseorang menjadi semakin cepat stress. Oleh karena itu diperlukan sebuah sarana yang dapat 
menyegarkan pikiran pada saat kita sedang merasa suntuk dan bosan dalam suatu pekerjaan dan bisa juga untuk mengisi waktu senggang.

Ruang publik semacam taman kota memiliki banyak sekali manfaat positif. Manfaat positif tersebut didapat dari pertemuan-pertemuan manusia secara fisik di ruang publik tersebut. Melalui pertemuan-pertemuan tersebut maka akan terlahir diskusi-diskusi kecil yang dapat mempererat hubungan antar manusia.

Maka di tiap wilayah sebaiknya tersedia beberapa fasilitas yang menunjang hal terkait dengan fasilitas publik dan sosial. Sebagai contoh pada Kawasan Kemayoran, Jakarta Pusat, daerah ini memiliki kegiatan bisnis dan perdagangan yang cukup padat. Berbagai macam kalangan masyarakat juga tinggal di sana, mulai dari masyarakat berpenghasilan sedang hingga tinggi. Akan tetapi, daerah sepadat ini hanya memiliki sedikit fasilitas sosial dan area hiburan. Selain itu Kemayoran juga merupakan salah satu kawasan masyarakat dengan kebudayaan yang cukup khas, yakni Betawi yang dapat menjadikan potensi didirikannya suatu wadah interaksi sosial yang digabungkan dengan sarana kreatif untuk mengekspresikan ekstensi kebudayaan mereka yang telah memudar.

\section{IDENTIFIKASI MASALAH}

a. Kemayoran merupakan kawasan yang sangat berpotensi di bidang perekonomian. Sehingga diperlukan wadah-wadah kreatifitas yang bisa memanfaatkan potensi tersebut.

b. Sibuknya kegiatan perekonomian di daerah tersebut mengakibatkan penatnya warga Kemayoran tetapi mereka belum difasilitasi tempat pelepas penat di kawasan ini.

\section{RUMUSAN MASALAH}

a. Bagaimana program dan kegiatan dalam third place yang dapat memenuhi kebutuhan masyarakat Kemayoran?

b. Bagaimana desain arsitektur yang selain dapat mengembangkan potensi warga Kemayoran, juga dapat memajukan daerah Kemayoran?

\section{TUJUAN PERANCANGAN}

a. Menyusun suatu konsep perancangan third place yang dapat memenuhi kebutuhan masyarakat Kemayoran akan suatu wadah yang dapat melepas penat sekaligus menambah penghasilan.

b. Menyusun suatu konsep perancangan dengan desain arsiterktur yang selain dapat mengembangkan potensi warga Kemayoran, juga dapat memajukan daerah Kemayoran.

\section{KAJIAN LITERATUR}

\section{Third place}

Third place merupakan tempat yang mempertemukan berbagai macam masyarakat yang menyediakan wadah aktivitas warga diluar kegiatan rutinitas rumah (1st place) dan rutinitas pekerjaan (2nd place). third place diperlukan bagi semua orang karena merupakan tempat dimana orang dapat melepaskan kepenatan yang terjadi pada aktivitas keseharian mereka.

Terdapat tujuh buah karakter dalam third place, yaitu merupakan tempat yang netral, mempunyai kedudukan yang sama, tidak ada hirarki maupun status, sebagai tempat untuk pertemuan didominasi dengan aktivitas perbincangan, pengunjung third place adalah pengunjung regular, third place merupakan bagian dari komunitas, tempat ini haruslah playful atau menyenangkan bagi siapapun (Berdasarkan materi kuliah yang disampaikan oleh Bapak Suwardhana Winata, S.T., M.Arch dalam kuliah tamu pada tanggal 1 Agustus 2019).

\section{Ruang Terbuka (Open Space)}

Ruang terbuka (open space) merupakan ruang terbuka yang selalu terletak di luar massa bangunan yang dapat dimanfaatkan dan dipergunakan oleh setiap orang serta memberikan kesempatan untuk melakukan bermacam-macam kegiatan. Macam-macam ruang terbuka 
antara lain jalan, pedestrian, taman lingkungan, plaza, lapangan olahraga, taman kota dan taman rekreasi (Hakim, $2003: 50$ ).

Ruang terbuka terbentuk karena adanya kebutuhan akan perlunya tempat untuk bertemu atau berkomunikasi satu sama lain. Dalam satu kawasan permukiman baik yang tradisional maupun permukiman kota sering kita jumpai sebuah alahan kosong yang dijadikan sebagai ruang bersama bagi penghuni yang ada di sekitarnya dengan jarak radius tertentu (Hartanto, 2015 dalam Bappeda Tk. I Bali , 1992 : 28).

Berdasarkan bentuk, macam dan fungsi, ruang terbuka dapat dibedakan menjadi tiga macam yaitu (Jayadinata, $1999: 33)$ :

a. Kebudayaan misalnya : lapangan olah raga, kolam renang terbuka, taman, kampus universitas, dan sebagainya.

b. Kehidupan ekonomi (mata pencaharian), misalnya : sawah, kebun, kolam, hutan, pasar, pelabuhan, dan sebgainya.

c. Kehidupan sosial, misalnya : kawasan rumah sakit, kawasan perumnas, tanah lapang untuk latihan militer, danau untuk rekreasi berperahu, dan sebagainya.

Pada dasarnya fungsi ruang terbuka dapat dibedakan menjadi dua fungsi utama yaitu (Hakim, $2003: 52)$ :

a. Fungsi Sosial, antara lain untuk tempat bermain dan sarana olahraga, tempat komunikasi sosial, tempat peralihan dan menunggu, tempat untuk mendapatkan udara segar, sarana penghubung satu tempat dengan tempat lainnya, pembatas diantara massa bangunan, sarana penelitian dan pendidikan serta penyuluhan bagi masyarakat untuk membentuk kesadaran lingkungan, sarana untuk menciptakan kebersihan, kesehatan, keserasian, dan keindahan lingkungan.

b. Fungsi Ekologis, antara lain untuk penyegaran udara, mempengaruhi dan memperbaiki iklim mikro, menyerap air hujan, pengendali banjir dan pengatur tata air, memelihara ekosistem tertentu dan perlindungan plasma nuftah, pelembut arsitektur bangunan.

Fungsi alam dapat dibedakan menjadi 2, yaitu (Hakim, 2003) :

a. Fungsi Psikologis

Kesenangan yang bersifat visual misalnya dengan digunakannya tumbuhan yang merambat dapat memperlunak garis-garis arsitekturnya.

b. Fungsi Fisik

Dapat mengurangi silau, mengurangi kegaduhan (alam buatan yang bersifat masif).

\section{Keterkaitan Open Space, Urban Space, dan Public Space}

Menurut Spreiregen (1965), jika ruang tersebut pembatasnya didominasi oleh unsur alam, maka ruang yang terbentuk disebut open space. Sedangkan jika material pembatasnya didominasi oleh unsur buatan (urban mass), maka ruang yang terbentuk disebut urban space. Urban space yang juga memiliki karakter open space, biasanya juga disebut dengan istilah urban open space.

Menurut Krier (1979), jika kita bisa mengabaikan kriteria estetis, maka pengertian tentang ruang kota cenderung mencakup semua ruang yang terletak di antara gedung-gedung dan bangunan lain. Kejelasan karakteristik dan estetislah yang memungkinkan kita menyerap ruangruang luar ini sebagai urban space / ruang kota

Sedangkan public space merupakan suatu ruang yang terbentuk atau didesain sedemikian rupa sehingga ruang tersebut dapat menampung sejumlah besar orang (publik) dalam melakukan aktifitas-aktifitas yang bersifat publik sesuai dengan fungsi public space tersebut (Ching, 1992). 

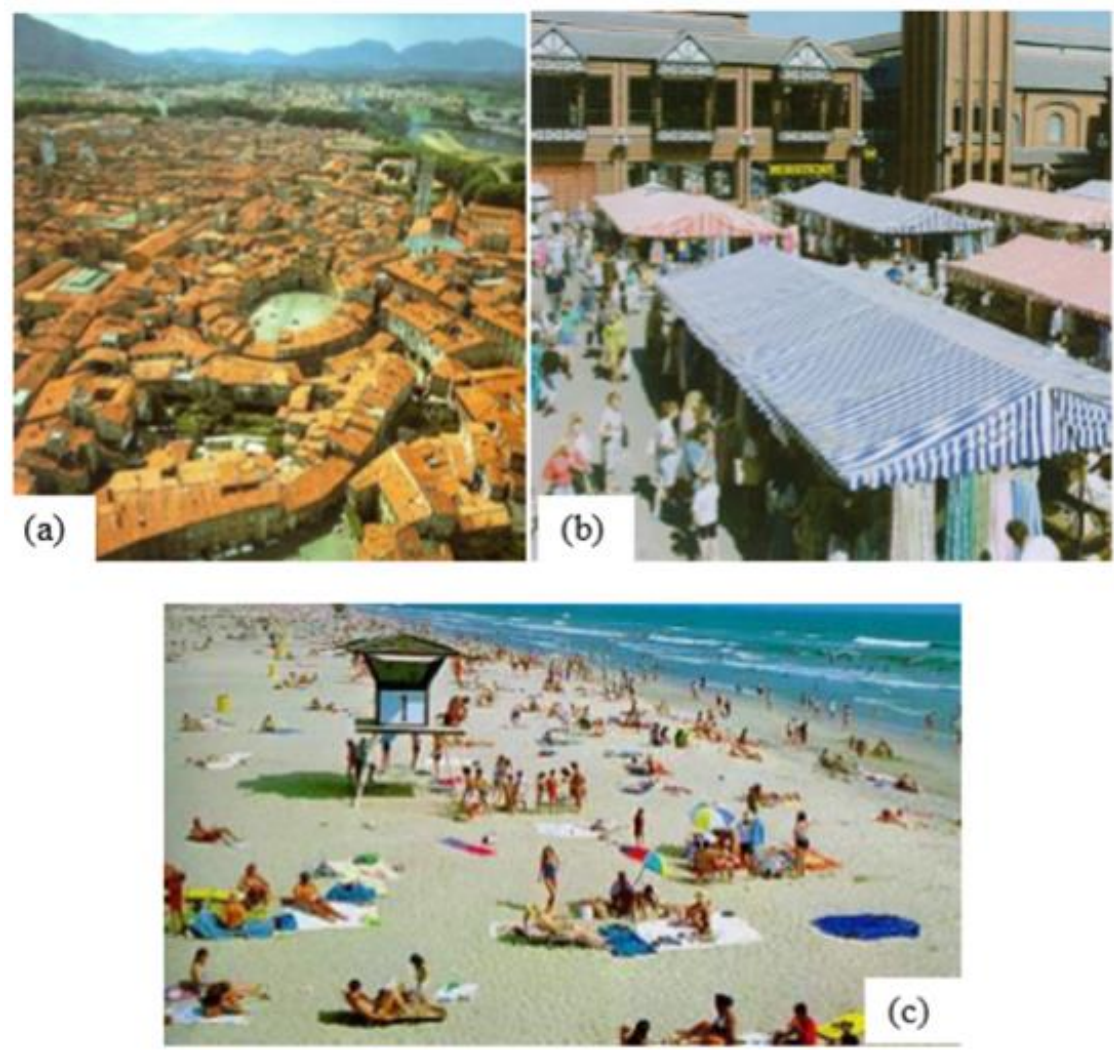

Gambar 1. (a) Open Space, (b) Urban Space, (c) Public Space

Sumber: Google, 2005

\section{Open Society}

Masyarakat terbuka (open society) adalah masyarakat yang bebas dari pengaruh kekuasaan atau tekanan dari negara itu sendiri. Masyarakat berpartisipasi aktif, dan terwujudnya demokrasi serta kebebasan untuk berpendapat dan berekspresi. Masyarakat terbuka juga berarti masyarakat yang mau menerima perubahan-perubahan yang terjadi di lingkungannya.

Tujuan diciptakannya konsep "open society" adalah untuk mewujudkan masyarakat yang memiliki kedewasaan dalam bersikap dan berpikir demokratis, menghormati pluralitas dalam tatanan nasional, menghargai pendapat orang lain.

Dalam menerima perubahan, pada masyarakat terbuka dibedakan menjadi dua kelompok, yaitu (Liu, 2018):

a. Masyarakat yang menerima perubahan dengan seleksi. Artinya perubahan yang membawa dampak positif bagi nilai-nilai di masyarakat tersebut akan diterima dengan tangan terbuka, sebaliknya perubahan yang dapat menimbulkan rusaknya norma-norma sosial akan ditolak keberadannya. Masyarakat ini tergolong sebagai masyarakat modern. Ciri-ciri masyarakat modern antara lain sikap hidup yang menerima hal-hal baru dan terbuka untuk perubahan, mempunyai keberanian untuk mengemukakan pendapat, lebih mengutamakan masa kini, dan sangat menghargai waktu, memiliki perencanaan dan pengorganisasian, yakin pada IPTEK (Ilmu Pengetahuan dan Teknologi), penuh perhitungan dan percaya diri, menghargai harkat hidup orang lain, memiliki sikap keadilan dan pemerataan.

b. Masyarakat yang menerima perubahan tanpa seleksi. Artinya, semua unsur-unsur yang masuk dalam suatu masyarakat dianggap baik sehingga perlu diikuti, terutama unsur-unsur budaya dari dunia Barat. Proses menerima semua unsur-unsur Barat tanpa seleksi disebut westernisasi. Padahal semua yang datang dari Barat tidak dapat digolongkan modern. Pergaulan bebas, seks bebas, merupakan kerusakan moral dan tidak sesuai dengan nilai dan norma bangsa Indonesia. Pada akhirnya, kita harus bersikap bijaksana, jangan sampai westernisasi melunturkan nilai dan norma-norma baik yang telah ada. 


\section{Creative Hub}

Creative hub merupakan sebuah frasa dalam bahasa Inggris yang memiliki pengertian "pusat kreatif" dalam bahasa Indonesia. Menurut Kamus Besar Bahasa Indonesia (2016), kreatif memiliki arti bersifat (mengandung) atau memiliki daya cipta, sedangkan pusat memiliki arti pokok pangkal atau yang menjadi pumpunan (berbagai-bagai urusan, hal, dan sebagainya).

Definisi creative hub atau pusat kreatif sebagai sebuah pokok pangkal dalam hal-hal yang berdaya cipta tidak hanya mencakup segi fisik saja, melainkan juga dari segi jaringan komunitas kreatif yang terbentuk dari pelaku-pelaku kreatif dan aktivitas-aktivitas yang dilakukan. Dari segi fisik, creative hub menyediakan tempat dengan ruang-ruang untuk bekerja bagi komunitaskomunitas kreatif sekaligus menjadi inkubator bisnis industri kreatif.

Secara fisik, creative hub hanya mencakup satu tempat sesuai esensinya sebagai sebuah pusat. Namun, aktivitas-aktivitas dalam creative hub menyatukan bakat, keterampilan dan disiplin pelaku-pelaku kreatif dalam suatu komunitas kreatif lokal. Creative hub membentuk suatu jaringan yang menggerakkan pertumbuhan industri kreatif dalam level lokal, yang kemudian berlanjut ke level regional. Creative hub menjadi ruang dinamis yang menyediakan lapangan pekerjaan lebih, memperluas layanan pendidikan, kesempatan networking dan pengembangan bisnis, serta menciptakan inovasi dengan lebih intensif dalam industri kreatif. Creative hub ini menjadi suatu cara baru untuk mengorganisasi inovasi dan pengembangan industri kreatif (Fardianda, 2015).

Creative hub atau pusat kreatif memiliki fungsi untuk (Panghegar, 2018):

a. Menyediakan fasilitas-fasilitas untuk mengembangkan industri kreatif Indonesia,

b. Menyediakan ruang bagi para pelaku industri kreatif yang membutuhkan tempat untuk mengerjakan dan mengembangkan kegiatan kreatifnya,

c. Menyediakan wadah bagi para pelaku kreatif untuk

d. mengembangkan bisnis kreatifnya,

e. Mengadakan program pelatihan dalam bidang-bidang subsektor industri kreatif,

f. Mengintegrasikan keseluruhan kegiatan subsektor industri kreatif sehingga terbentuk jaringan kreatif yang mampu meningkatkan pengetahuan masyarakat Indonesia dan wisatawan asing akan produk-produk kreatif Indonesia.

\section{Sejarah Kota Baru Kawasan Kemayoran}

Pada mulanya penduduk Kampung Kemayoran adalah orang Betawi. Kedatangan Belanda ke Jakarta sebagai bangsa penjajah banyak membutuhkan tenaga dari luar untuk dijadikan pekerja. Pemerintah Belanda mendatangkan orang-orang dari Cina, India, Sumatera dan Indonesia bagian timur. Dengan adanya bangsa-bangsa tersebut terjadilah asimilasi dan akulturasi perkawinan diantara mereka dan membentuk masyarakat Betawi dengan berbagai keragaman budaya yang khas.

Di bawah pemerintahan gubernur Jendral Daendels, pembangunan jalan dibiayai dengan cara menjual tanah kepada orang-orang kaya. Hal ini terjadi pula pada tanah di Kemayoran, umumnya pembelinya dari kalangan orang-orang kaya atau tuan tanah. Kekuasaan tuan tanah juga diberikan oleh pemerintah Belanda. Mereka berhak mengatur kembali tanah yang sebelumnya mereka adalah budak belian. Setelah perbudakan dihapus, mereka menjadi petani milik tuan tanah dan umumnya tuan tanah akan menentukan besaran pajak yang harus di bayar.

Karena Kemayoran sekarang daerahnya sudah berubah menjadi tempat pemukiman, banyak di antara mereka yang mengalihkan mata pencahariannya yakni dari petani ke usaha-usaha lain seperti pedagang, buruh pabrik, bengkel dan lain-lain. Dengan dibangunnya Lapangan Terbang Kemayoran sekitar tahun 1935, penduduk membuka usaha sebagai pedagang keliling, berjual alat-alat rumah tangga dan lain-lain. Sudah menjadi tradisi bagi tuan-tuan tanah di daerah Kemayoran pada tiap-tiap tahun baru Cina, mereka mengadakan suatu pesta perayaan dengan acara pertunjukan sebagai hiburan bagi rakyat yang memperkenalkan kesenian rakyat yang sangat digemari pada saat itu misalnya kesenian Keroncong, Wayang Kulit, Gambang Kromong, Der Muruk dan lain-lain (Kampung Tua di Jakarta, Dinas Museum dan Sejarah, 1993). 


\section{METODOLOGI}

\section{Metode Pengumpulan Data}

Metode yang digunakan penulis dalam makalah ini adalah model pendekatan riset dengan metode deskriptif kualitatif. Pengumpulan data dilakukan dengan beberapa cara, yaitu:

a. Observasi

Obeservasi dilakukan untuk mengetahui secara langsung kondisi fisik dan kondisi sosial Kawasan Kemayoran. Teknik ini dilakukan dengan beberapa kegiatan diantaranya pengamatan kondisi fisik dan sosial, pemetaan, pencatatan dan dokumentasi pribadi.

b. Wawancara

Wawancara adalah kegiatan tanya jawab yang dilakukan dengan interaksi langsung dengan masyarakat Kemayoran. Wawancara dilakukan untuk mengetahui pendapat penduduk Kemayoran mengenai area tersebut sehingga dapat mengenal kawasan lebih dekat. Wawancara dilakukan dengan berbagai usia narasumber untuk mendapat beberapa sudut pandang.

c. Kajian teoritis

Penelitian ini juga menggunakan berbagai teori yang relevan dengan konteks permasalahan dan menganalisa penelitian-penelitian terdahulu yang sejenis. Kajian teoritis dilakukan dengan cara membaca, menganalisa, meringkas, dan mengutip.

d. Data statistik

Penelitian ini juga melakukan pengamatan terhadap data statistik Kawasan Kemayoran untuk mengetahui data kuantitatif kawasan demi keakuratan penelitian.

e. Peta Kognitif

Peta kognitif dibuat untuk memudahkan menganalisa Kawasan Kemayoran dalam aspek ruang kota, di bidang Arsitektur. Hal ini bertujuan untuk mengetahui ruang kota, jarak, dan lainlain.

\section{Metode Desain}

Metode desain yang digunakan dalam perancangan proyek Wadah Interaksi Sosial dan Sarana Kreatif di Kemayoran, Jakarta Pusat ini adalah metode transprogramming dari Bernard Tchumi. Transprogramming yaitu mengkombinasikan dua program yang sifat dan konfigurasi spasialnya berbeda tanpa melihat kecocokannya. Misalnya perpustakaan dikombinasikan dengan arena balap. (Tchumi, 1996)

Konsep utama dari bangunan ini adalah sebagai wadah yang dapat mempererat interaksi sosial dan menunjangnya dengan sarana kreatif untuk mengembangkan potensi warga daerah Kemayoran, Jakarta Pusat sehingga sekaligus dapat memperbaiki taraf kehidupan. Oleh karena itu metode yang di ambil adalah metode transprogramming, yaitu mengkombinasikan dua program yang sifat dan konfigurasi spasialnya berbeda tanpa melihat kecocokannya.

Program-program yang dikombinasikan tersebut akan memberikan dampak yang positif. Contohnya program workshop dengan program exhibition yang dimana hasil kerajinan yang di olah dalam workshop dapat dipamerkan dan dijual di area exhibition. Hal ini dapat mengajarkan para pengunjung bahwa keterampilan bukan hanya sekedar minat dan bakat, tetapi dapat meningkatkan kondisi ekonomi.

\section{DISKUSI DAN HASIL}

Proyek ini berjudul Wadah Interaksi Sosial dan Sarana Kreatif di Kemayoran, Jakarta Pusat yang memiliki tujuan untuk mendukung eratnya interaksi sosial dengan berbagai macam kegiatan dan mendukung minat dan bakat warga sehingga mereka dapat menyadari potensi dalam diri masing-masing. Beberapa aspek dasar dalam perancangan program yaitu aspek sosial, ekonomi, dan seni budaya.

\section{Tinjauan Lokasi Dan Tapak}

Pemilihan tapak untuk proyek Wadah Interaksi Sosial dan Sarana Kreatif di Kemayoran, Jakarta Pusat ini memiliki beberapa kriteria berdasarkan analisis kebutuhan dan jenis program 
di dalamnya, antara lain:

a. Berada di jalan kolektor sekunder agar akses kendaraan mudah dan dilihat banyak pengunjung

b. Berada di zonasi campuran, perdagangan dan jasa, atau pelayanan umum dan sosial

c. Lokasi berada di titik lokasi yang ramai, dekat dengan hunian dan tempat bekerja sehingga mudah untuk dicapai

d. Berada di daerah yang banyak akses kendaraan umum

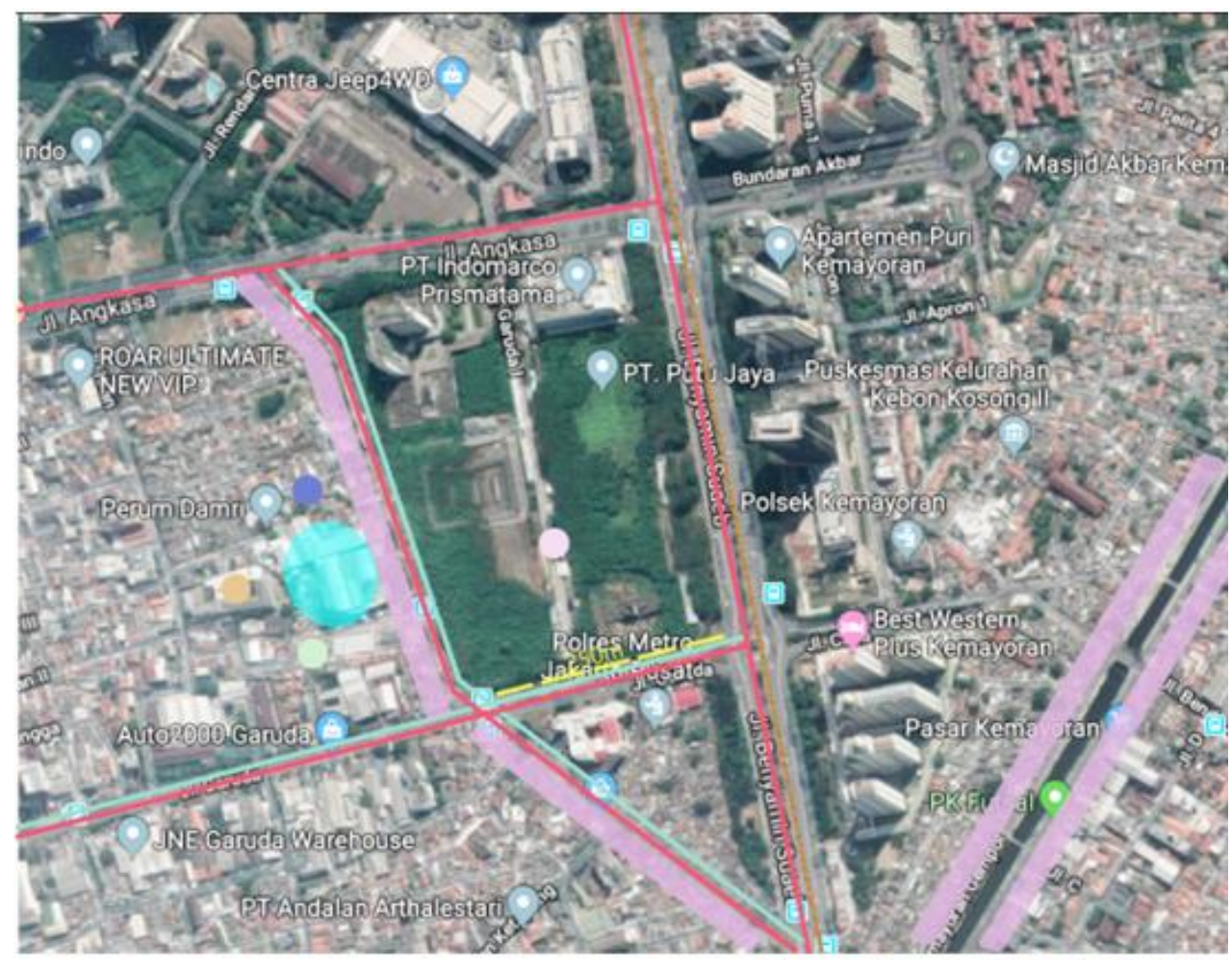

Legenda:

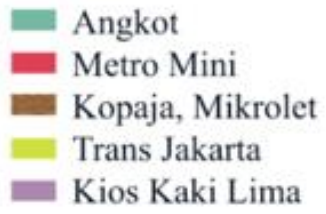

Rencana Tapak

Sekolah

Terminal DAMRI

Hunian

Pasar Malam

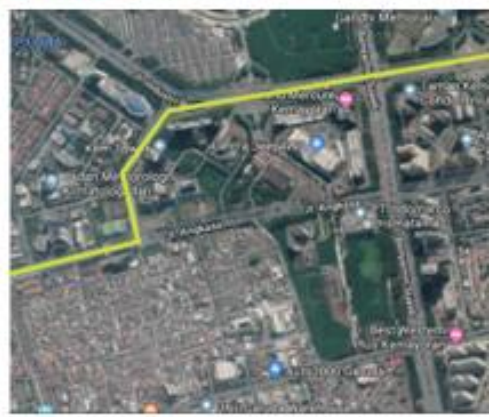

Gambar 2. Pemetaan fungsi bangunan sekitar site

Sumber: Penulis, 2019

Tapak yang dipilih berada di samping Terminal Damri dan sangat dekat dengan sekolah, sehingga akan memperbesar peluang ramainya pengguna bangunan dan pengunjung. Potensi untuk mengembangkan daerah tersebut menjadi lebih rapi dan layak juga dapat di kembangkan dengan menambahkan food court baru tanpa harus bersaing dengan pasar malam yang ada. Daerah tapak dekat dengan hunian, pabrik, sekolah, perkantoran, dan kios-kios kaki lima sehingga mudah untuk di raih.

Tapak terpilih dengan keadaan eksisting pabrik yang tidak sesuai dengan peruntukan zonasi juga menjadi potensi keberhasilan dibangunnya proyek ini. Keadaan eksisting area tapak ini adalah zona coklat (zona pelayanan umum dan sosial) dimana tidak sesuai dengan pabrik. 
Dari segi akses juga akses ke daerah ini dapat di raih dari segala arah. Akan tetapi, jika diraih menggunakan Trans Jakarta harus di sambung dengan Metro Mini agar dapat sampai ke tapak.

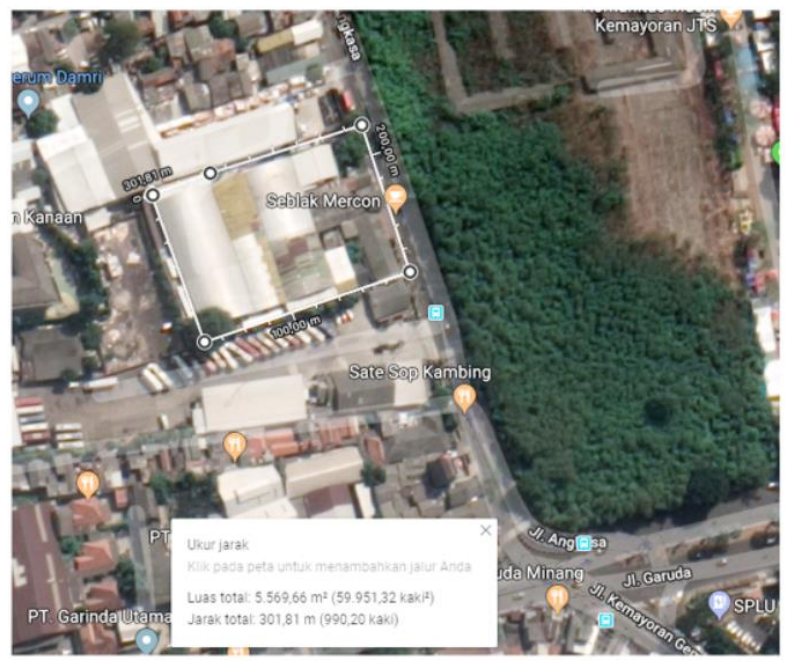

Profil Lahan:

Luas tapak: 5569m2

KDB: $40 \%$

KLB: 2

$\mathrm{KDH}: 30 \%$

KB: 4

KTB: $55 \%$

Zona Pelayanan Umum dan Sosial

Gambar 3. Peta rencana tapak

Sumber: Penulis, 2019

\section{Tijauan Kebutuhan}

Berdasarkan jenis aktivitas yang berada pada bangunan sekitar tapak, maka dapat disebutkan bahwa kebutuhan masyarakat dibagi menurut $1^{\text {st }}$ place dan $2^{\text {nd }}$ place yang kebutuhan tersebut akan diselesaikan dalam third place. Pada $1^{\text {st }}$ place terdapat hunian dengan mayoritas usia produktif diikuti dengan usia balita dan lansia. Pada $2^{\text {nd }}$ place terdapat sekolah TK hingga SMA, kantor, hingga kios. Dengan keadaan seperti ini maka dibutuhkan tempat bersantai untuk sekedar jalan-jalan dan makan, tempat berolahraga umum yang menunjang segala usia, dan arena untuk berdiskusi. Permasalahan khusus seperti minat dan bakat yang kurang diwadahi mengarahkan untuk dibangunnya program seperti workshop.
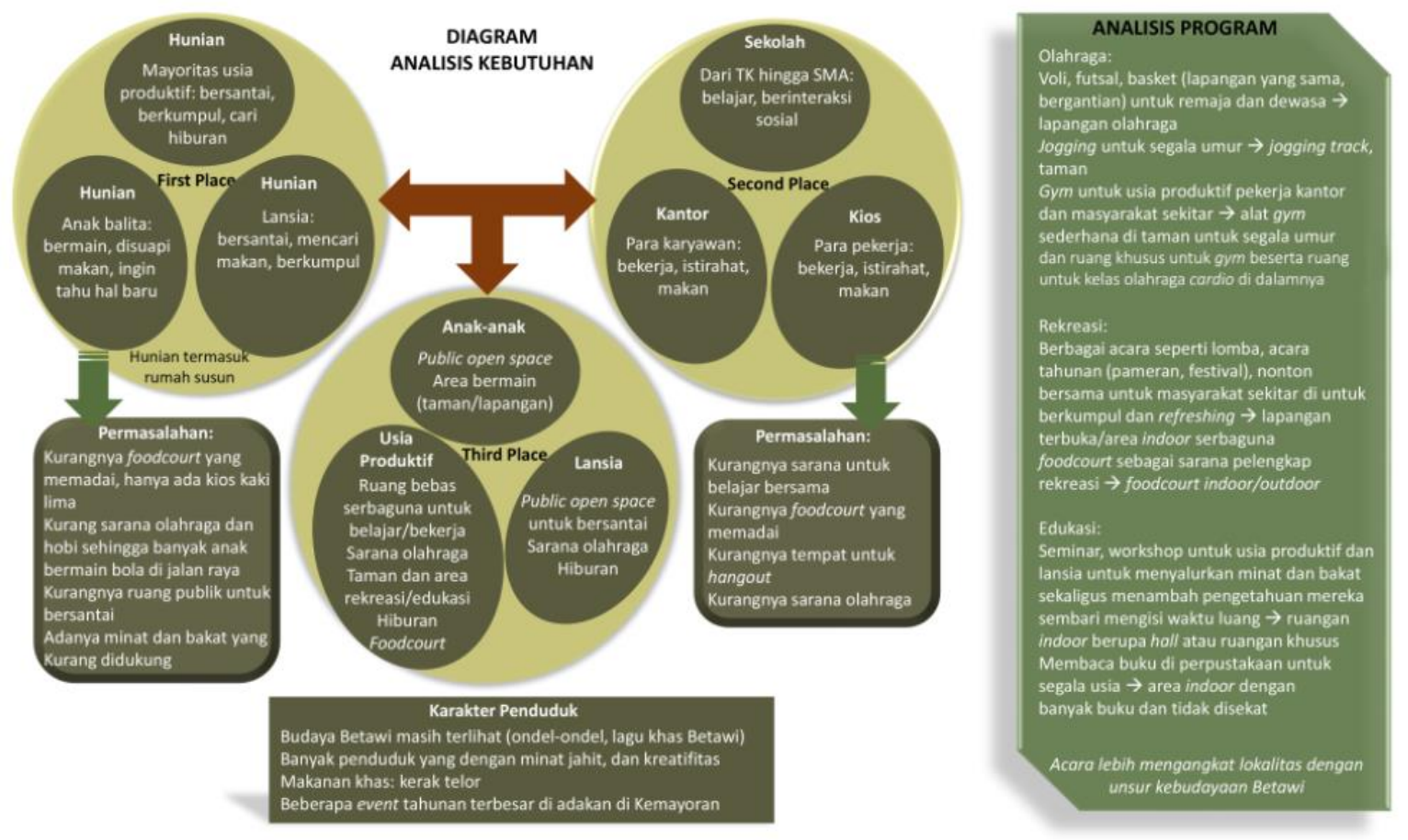

Gambar 4. Diagram analisis kebutuhan Sumber: Penulis, 2019 


\section{Program}

Program berasal dari hasil metode transprogramming dan analisis kebutuhan bangunan, yaitu mengkombinasikan dua program yang sifat dan konfigurasi spasialnya berbeda tanpa melihat kecocokannya. Konsep yang diusung adalah suatu tempat dimana warga Jakarta bisa datang dan meredakan stress serta mencapai keadaan sehat di tengah - tengah hiruk pikuk kota metropolis yang juga akan menguak minat dan bakat mereka lebih dalam sehingga menghasilkan potensi-potensi yang positif.

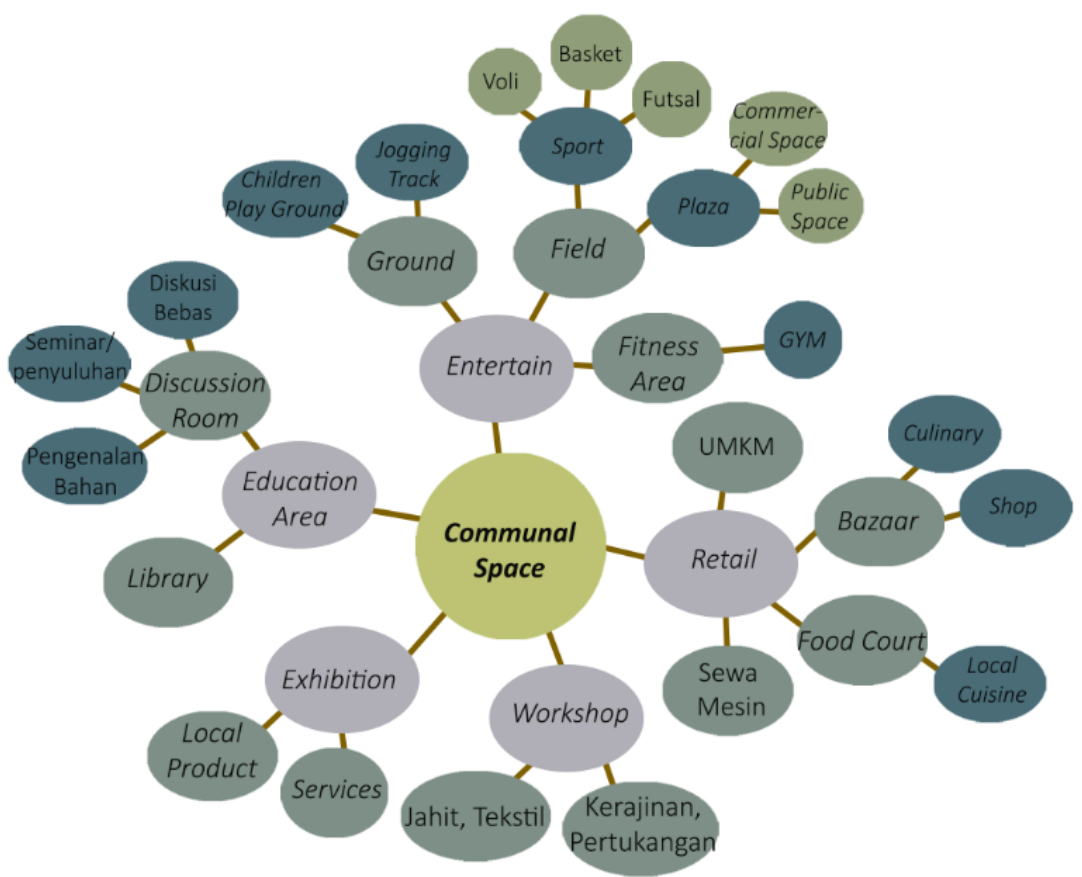

Gambar 5. Diagram program bangunan

Sumber: Penulis, 2019

Program dikelompokkan dalam beberapa area, antara lain workshop, retail, entertain, education area, dan exhibition. Program yang menciptakan ruang yang satu dengan yang lain akan saling mendukung sedemikian rupa sehingga menjadi satu kesatuan bangunan yang mengkontaminasi satu sama lain. Adapun pengelompokkan ruang berdasarkan jenis programnya adalah sebagai berikut.

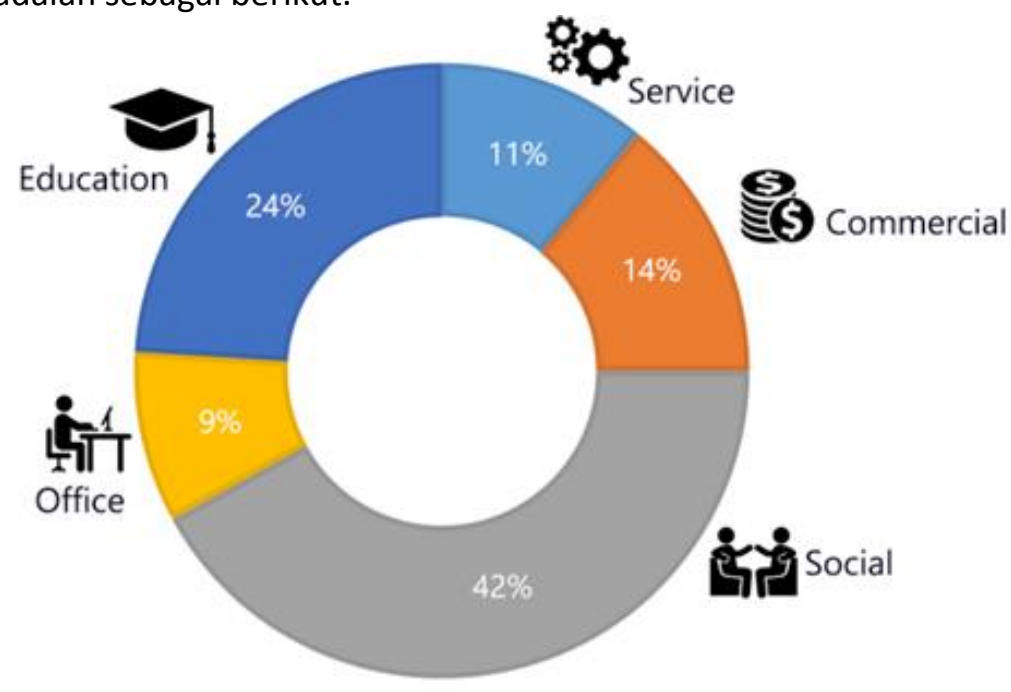

Gambar 6. Program ruang dalam persen Sumber: Penulis, 2019 


\section{Konsep Perancangan}

Ide bentuk bangunan diterapkan berdasarkan metode metafor dimana bentuk kupu-kupu menjadi dasar bentuk dari bangunan ini. Mengacu pada sifat kupu-kupu jika sedang mencari makan di taman seakan senang berkumpul dan seakan bergurau dengan teman-temannya.

(senang bersosialisasi, akrab, indah)

Ide dasar tersebut muncul karena bangunan lingkungan sekitar tapak. Terminal Damri yang berada di sebelah tapak penuh dengan hiruk-pikuk keramaian dan menjadi tempat bertemunya orang dari berbagai daerah. Hal tersebutlah asal dari ide yang menggunakan metode metafor ini. Proses perubahan bentuk dari ide dasar menjadi sebuah bentuk bangunan adalah sebagai berikut:
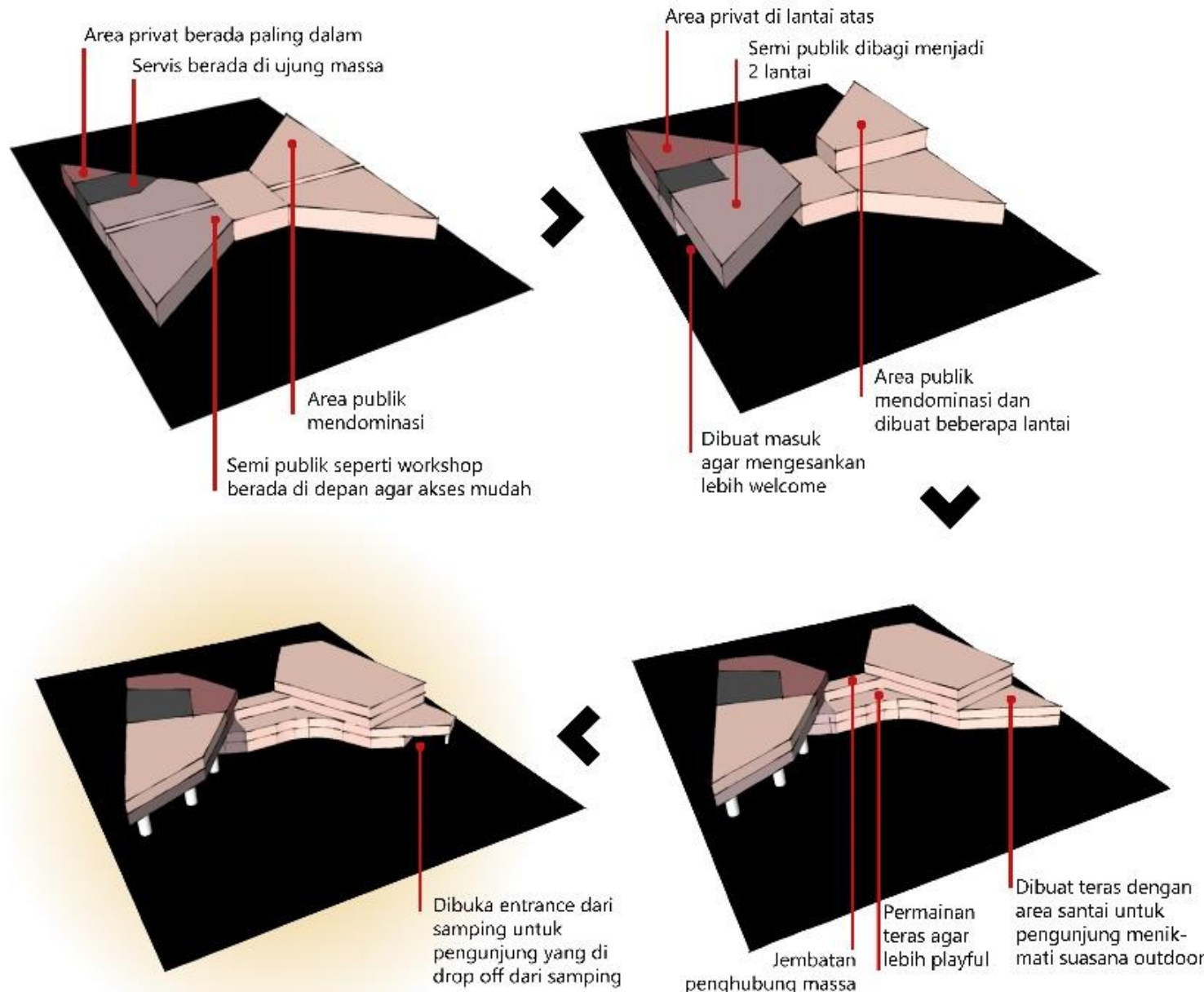

Gambar 7. Proses gubahan massa

Sumber: Penulis, 2019

Pembagian letak ruang adalah berdasar konsep zoning dan lokasi. Area privat diletakkan di area bangunan bagian dalam, servis di letakkan di daerah pinggir, dan didominasi oleh area publik yang berada di tengah dan depan. Area drop-off dibuat hanya dari depan karena akses utama seluruhnya hanya dari depan.

Untuk transportasi dalam bangunan, dapat menggunakan alternatif, yaitu lift, tangga, dan eskalator. Namun, untuk eskalator hanya melayani sampai lantai dua.

Disangkutkan dengan konsep yang "terbuka"dan "playful", bangunan ini dibuat dengan banyak bukaan dan void. Selain itu, fasad bangunan sebagian besar menggunakan material kaca dan atap yang sangat tropis. 


\section{HASIL PERANCANGAN}

Hasil akhir berupa bangunan 4 lantai dengan pembagian ruang lantai 1 berupa workshop, exhibition area, dan plaza dilengkapi dengan sarana olahraga seperti jogging track, lapangan basket/futsal/voli pada bagian outdoor. Pada lantai 2 terdapat workshop, food court, UMKM, dan experience area. Hampir setiap ruang workshop selalu diberikan ruang pendukung untuk area pamer (exhibition area/UMKM). Untuk lantai 3 juga terdapat workshop, perpustakaan umum, dan kantor pengelola. Di lantai 4 dikhususkan untuk area gym yang difasilitasi dengan ruang bilas dan loker.

Untuk area servis dan maintanance gedung, dikhususkan dan dikumpulkan pada area basement sehingga antara sirkulasi servis dengan pengunjung tidak bertabrakan.

Berikut adalah denah aksonometri yang menjelaskan zoning ruang dan nama ruang di dalamnya.

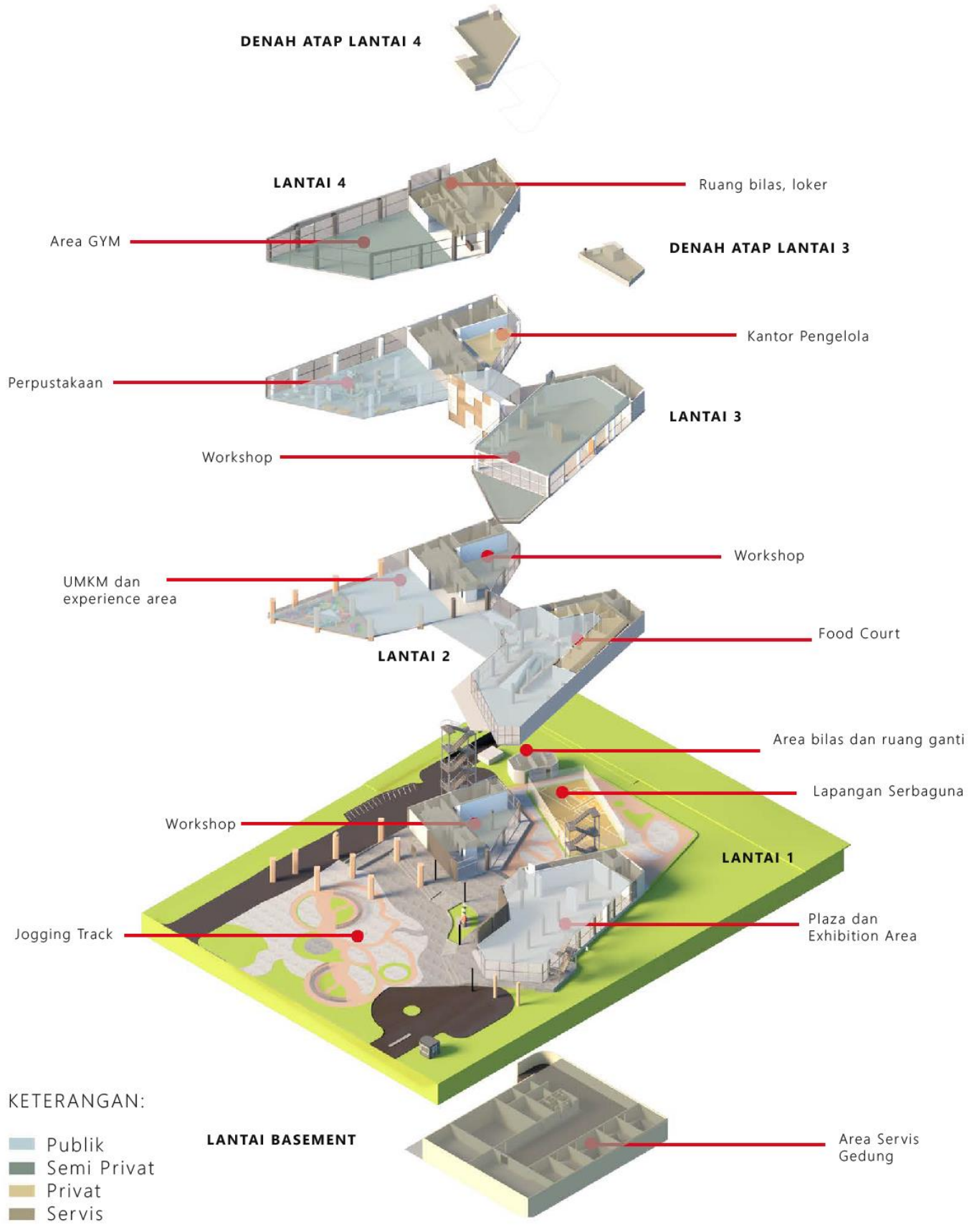

Gambar 8. Denah aksonometri

Sumber: Penulis, 2019 
Fasad bangunan didominasi dengan kaca untuk memberikan kesan "mengundang dan menerima". Bagian atap dibuat berundak sebagai variasi dengan desain struktur tektonik sebagai pendukung. Unsur kebudayaan juga dicampurkan dalam fasad seperti dominasi bentuk tajam (di anggap penolak bala oleh masyarakat Betawi) dan motif batik Betawi pada bagian depan. Ondel-ondel juga menjadi bagian dalam bangunan ini sebagai ornamen. Patung ondelondel diletakkan pada bagian entrance sehingga dapat jelas dilihat oleh pengunjung saat masuk.

Berikut adalah gambar fasad bangunan dimana (a) adalah tampak depan, (b) adalah tampak belakang, (c) adalah tampak kanan, dan (d) adalah tampak kiri.

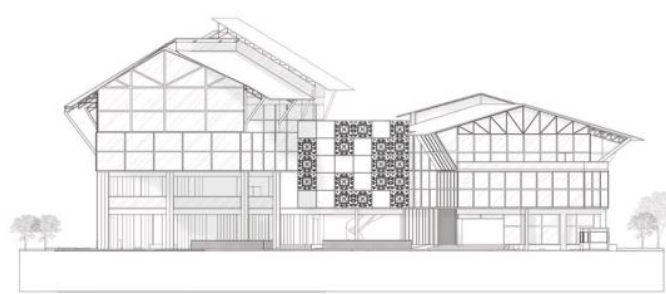

(a)

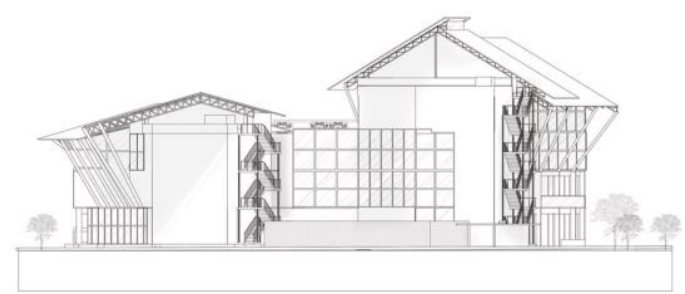

(b)

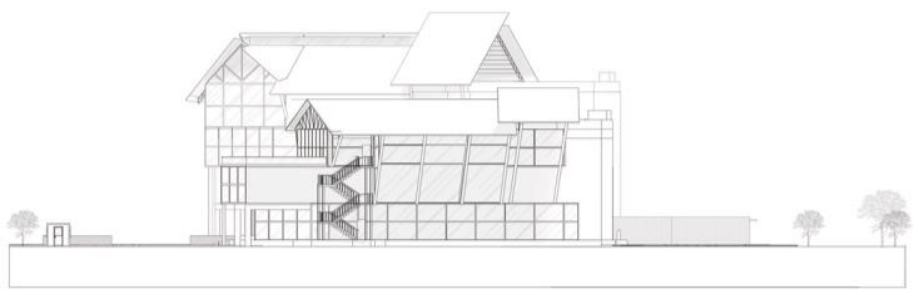

(c)

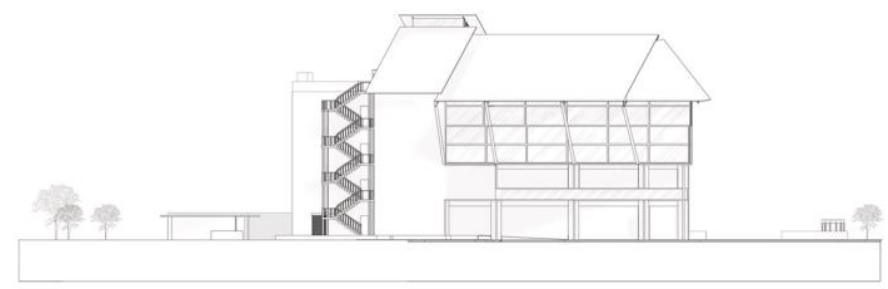

(d)

Gambar 9. Tampak

Sumber: Penulis, 2019

Sedangkan gambar berikut adalah potongan bagunan dimana (a) adalah potongan $A-A,(b)$ adalah potongan $B-B$, (c) adalah potongan $C-C$, dan (d) adalah potongan $D-D$ yang memperlihatkan struktur atap hingga bangunan dan beberapa hubungan antar ruang dalam bangunan. 


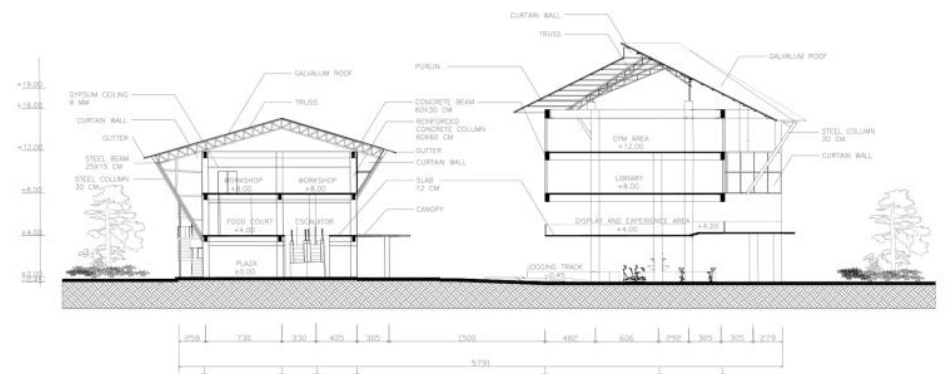

(a)

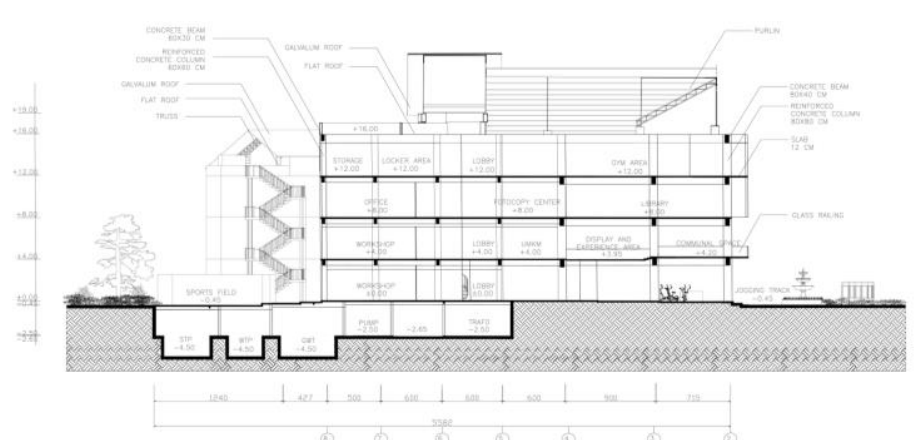

(b)

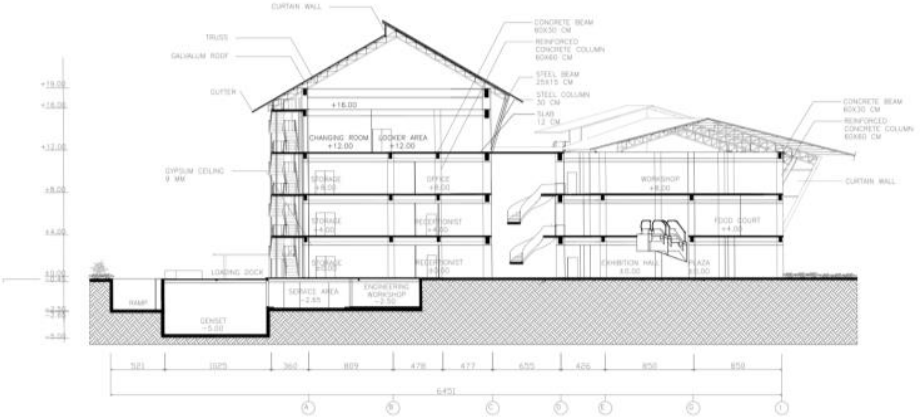

(c)

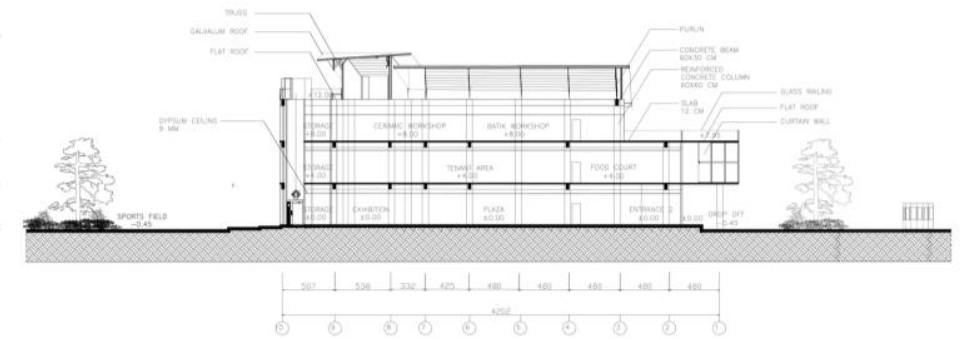

(d)

Gambar 10. Potongan

Sumber: Penulis, 2019

\section{KESIMPULAN DAN SARAN}

Pembangunan proyek Wadah Interaksi Sosial dan Sarana Kreatif (Social Station and Creatif Hub) ini dirasa sangatlah perlu, karena program dalam proyek ini masih sangat kurang di Kawasan Kemayoran. Program yang diadakan dikaitkan dengan misi sosial yang dipadukan dengan berbagai kegiatan dan acara yang membangun kreatifitas dan menambah pengetahuan serta misi untuk mengembalikan identitas kebudayaan Betawi yang telah tergerus oleh modernisasi. Bagian bangunan pun tidak seluruhnya ruang yang mengharuskan untuk 
berinteraksi, namun juga ada bagian yang lebih privat untuk menghargai orang yang ingin menikmati waktu dengan dirinya sendiri. Bangunan ini juga dikembangkan ke arah hobi, minat dan bakat warga.

Untuk merencanakan third place di Kawasan kemayoran perlu mempertimbangkan aspekaspek seperti lokasi yang dilewati transportasi umum, dekat dengan first place dan second place, dan berada pada lapisan sekunder sehingga dapat membaur dengan masyarakat.

Proyek bangunan dan kegiatan ini di harapkan akan mengubah cara berpikir dan anggapan masyarakat untuk lebih membuka diri kepada masyarakat sosial untuk saling mengenal dan bertukar pikiran. Dengan kegiatan yang diadakan dalam program diharapkan membuat pengunjung sadar bahwa untuk menjalin keharmonisan seharusnya tidak memandang umur dan status sosial.

\section{REFERENSI}

Angkutanumum.com. Mikrolet M35. n.d. www.transportumum.com/jakarta/mikroletm-35/. Diakses tanggal 7 Agustus 2019.

British Council. (2015). Creative Hub Toolkit. http://creativeconomy.britishcouncil.org/blog/15/06/28/creative-hubkitmadehubs-emerging-hubs/. Di akses tanggal 28 Agustus 2019.

Ching, F.D.K. (1979). Arsitektur: Bentuk-Ruang dan Susunannya. Jakarta: Penerbit Elangga. Hakim, R. (1995). Peran Arsitektur Lansekap Dalam Wilayah Perkotaan. FALTL Universitas Trisakti, Jakarta.

Hakim, R. (1996). Tahapan dan Proses Perancangan dalam Arsitektur Lansekap. Penerbit Bina Aksara Jakarta

Hakim, R. (2004). Arsitektur Lansekap, Manusia, Alam dan Lingkungan. Jakarta: FALTL Universitas Trisakti.

Hartanto. (2015). Pengertian Ruang Terbuka dalam Bappeda Tk. I Bali. $1992<$ http:// perilaku-manusia-pada-open-space.html di akses 27/12/2019

Jayadinata, T. J. (1999). Fungsi Ruang Terbuka. Bandung: Institut Teknologi Bandung.

Kampung Tua di Jakarta (2008), Dinas Museum dan Sejarah, 1993

Kamus Besar Bahasa Indonesia. [Online]. <https://kbbi.kemdikbud.go.id/entri/kreatif diakses tanggal 21 Januari 2020

Krier, R. (1979). Urban Space. New York: Rizzoli International Publications.

Kompasiana.Ruang Publik Bukan Alternatif Hiburan Masyarakat.30 September 2015.https://www.kompasiana.com/yongkyyulius/560ba2e10e97736e071c61d7/r uang-publik-bukan-alternatif-hiburan-masyarakat. 28 Agustus 2019

Liu (2018). Dilema Masyarakat Terbuka (Open Society). Jakarta: Kompasiana

Panghegar. (2018). Interior "KOLASE" Creative Hub sebagai Upaya Pengembangan Ekonomi Kreatif di Surabaya. Jurnal Intra Vol. 6, No. 2

Pemerintah Daerah Khusus Ibukota Jakarta, Dinas Museum dan Sejarah. (1993). Kampung Tua di Jakarta. Jakarta

Perpustakaan Nasional. (2015). Asal mula Kampung Kemayoran.

Diskominfomas, Bang Jay Salim di Gue Anak Kemayoran http://bataviadigital.perpusnas.go.id/wilayah/?box=detail\&id_record=11 diakses tanggal 28 Agustus 2019.

Rizky I., K. (2014) "Rancangan Gedung Pameran Tetap dalam Komplek Museum Sonobudoyo, D.I Yogyakarta." Skripsi (2014): 10.

Spreiregen, P.D. (1965). Urband Design - The Architecture of City and Town. New York : McGraw Hill.

Winata, S. (2019), The Third place. Materi Kuliah Stupa 8 Prodi SS1 Arsitektur UNTAR. Jakarta

Tchumi, B. (1996). Architecture and Disjuction. MIT Press. 